\title{
SOCIO-SPATIAL SELF-SEGREGATION BY HOUSING AND THE ACCESS TO CITIZENS' RIGHTS
}

\author{
D. C. MONTEIRO ${ }^{1}$, F. Y. SHIBAO ${ }^{2}$, D. DE M. CONTI $^{3}$ e L. F. DA SILVA ${ }^{4}$ \\ Universidade Nove de Julho ${ }^{1,4}$, Universidade Ibirapuera², Pontifícia Universidade Católica de Campinas ${ }^{3}$ \\ davidcmonteiro@hotmail.com ${ }^{1}$
}

Submetido em 27/03/2018 e aceito em 05/02/2020

DOI: $10.15628 /$ holos.2020.7143

\begin{abstract}
The purpose of this article is to promote reflection on the relationship between access to housing as an instrument to promote citizens' rights and socio-spatial selfsegregation. It should be noted that the segregation treated here can be caused by physical barriers or not, since it also passes through a separation of behaviors and values, being in this article debated under the bias of the socio-spatial self-segregation by housing. Therefore, it was necessary to understand housing distribution systems extending from high-standard horizontal condominiums on one side, to invasions of peripheral areas such as wellsprings and hillsides on the other. This situation is result of the arising real estate explorations
\end{abstract}

and emergent middle class searching for new housings, it has shown more and more the intersection of these realities. A relevant finding in this study was that the desire to self-immunize from different living standards leads to urbanistic and psycho-sociocultural implications which directly impacts on how public and private services are delivered to individuals. Thus, a person's address can determine their level of access to sanitation, mobility, safety, education, health, etc. Furthermore, we sought a visualization of reality, indicating "what" and "where", creating a spatial and relational vision, seeking to identify "the place of each one" in the different Brazilian cities.

\section{A AUTOSSEGREGAÇÃO SOCIOESPACIAL PELA MORADIA E O ACESSO AOS DIREITOS CIDADÃOS}

\section{RESUMO}

O objetivo deste artigo é promover a reflexão sobre a relação entre o acesso à moradia como instrumento de promoção de direitos aos cidadãos e a autossegregação socioespacial. Destaca-se que a segregação aqui tratada pode se dar por barreiras físicas ou não, pois passa também por uma separação de comportamentos e valores, sendo neste artigo debatida sob o viés da autossegregação socioespacial pela moradia. Para tanto, se fez necessário compreender os sistemas de distribuição de moradias que vão desde condomínios horizontais de alto padrão de um lado, até as invasões de áreas periféricas como mananciais e encostas de morros. Esta situação é resultado do crescimento das explorações imobiliárias e da classe média emergente buscando por novas moradias, mostrando cada vez mais a interseção dessas realidades. Um achado relevante foi que o desejo de se auto-imunizar de padrões de vida diferentes leva a implicações urbanísticas e psicossocioculturais, o que impacta diretamente em como os serviços públicos e privados são entregues aos indivíduos, portanto, o endereço de uma pessoa pode determinar seu nível de acesso a saneamento, mobilidade, segurança, educação, saúde etc. Assim, procurou-se uma visualização da realidade, indicando "o que" e "o onde", criando uma visão espacial e relacional, buscando identificar "o lugar de cada um" nas diversas cidades brasileiras.

PALAVRAS-CHAVE: Direitos; Moradia; Segregação socioespacial; Autossegregação. 


\section{INTRODUCTION}

Although housing, in general, is only considered as protection, it should be addressed in a more complex way. A house can not be categorized in a simple way, or with a limited thought in which its description is given only by a set of walls covered by a roof. It is necessary to insert issues related to housing that involve security and freedom of access goods and services in a fair and wellmanaged society (Sen, 2000; UNHABITAT, 2014; Vianna, 2016).

The Brazilian metropolitan areas suffered a great impact from the proliferation of large real estate developments that were responsible for deeply changing their landscapes (Sanfelici, 2016; Mendonça, Andrade, \& Diniz, 2019). However, it is worth mentioning that there was a large population exclusion from the formal real estate market, which led to inadequate housing conditions, leading marginalized individuals to progressively occupy unincorporated areas of the formal real estate market or even areas that should not be housed. These new areas, which are often recognized such as invasions, do not have the basic infrastructure necessary for human subsistence (ONU, 2014; Ferreira \& Biasotto, 2012; UNHABITAT, 2014).

The areas that have undergone irregular processes of occupancy for housing construction are precarious, which causes problems to its occupants and the other people that live around these localities. These problems are often related environmental issues such as occupation of wellsprings and hillsides areas, as well as those related to the lack of adequate public services such as sanitation, potable water, access to electricity, among others, which make it unhealthy for people to stay in these areas (Reani \& Segalla, 2006; Spörl \& Seabra, 2011). Meanwhile, there are individuals in society who have access to a housing category that includes public and private goods and services available in a fair society a few meters from the same location.

An interesting aspect of these two realities is that with the increase of population density in regions such as São Paulo (Hughes, 2004; Campos \& Almeida 2016), it allows perceiving more frequently the intersection of these two categories of housing. The justification for this fact is that, previously, populations that did not have access to public goods and services were concentrated in peripheral regions, and these localities also became environments for the exploitation of housing of various social strata. This reality can be evidenced in Costa and Tavares (2009) research about horizontal condominiums in Natal, and Barbosa and Costa (2011) research about the socio-spatial implications of horizontal condominiums in João Pessoa. Therefore, both the increase of lowincome housing units and the distribution of private enterprises outside the central zones led to this intersection of realities.

It is worth mentioning that the intersection between these two houses categories generates mechanisms of defense by individuals with greater resources possibilities. These mechanisms can be perceived through physical barriers such as strapping walls. Furthermore, the result of these mechanisms for the construction of barriers promotes social segregation, and this scenario impacts on the lack of interaction between the two categories so far called housing (Negri, 2010), which also creates what can be called socio-spatial self-segregation. In this way, it is important to note that all social division in the geographical space expresses forms of segregation, and that the uses of this term, as well as self-segregation, represent concepts that distance themselves from the harmonious and collective view of a fair social life in a common space. 
Thus, social-spatial self-segregation is related to the idea of the separation of certain social groups in the space destined to the social collectivity. It can be considered as a consequence, or manifestation of social relations, that is established naturally in contemporary societies. Regarding spatial segregation, the possibility of having access to land or a building already built, in different places and at different prices, it has also been a point of reflection (Hughes, 2004; Campos \& Almeida, 2016; Mendonça, Andrade, \& Diniz, 2019). In addition, stratification by the means of rules and codes of conduct serves as a delimiter of physical space. In reality, socio-spatial self-segregation expresses a greater concentration of a particular social group in a given city or region.

Therefore, this article aims to promote reflection on the relationship between access to housing as an instrument to promote citizens' rights and socio-spatial self-segregation. To do so, this article intent to present how access to decent housing can provide access to citizens' rights. Moreover, it is important to understand that the intersections of distinct social realities are present even with the construction of walls that block their view (Sassen, 1994). It is also important to study the socio-spatial self-segregation process to understand the manifestations of social inequality in the areas belonging to cities, such as in the Schmidt, Mendes and Töws (2013) study.

\section{ACCESS TO DECENT HOUSING TO ACCESS CITIZENS 'RIGHTS}

The type of housing mentioned in this article is not only related to protection for individuals, i.e., to maintain their security. The housing issue here is seen as the means to achieve citizenship. Based on this premise, it is worth noting that access to adequate housing was recognized as a human right in 1948, with the Universal Declaration of Human Rights (ONU, 2014). Thus, housing has become a universal human right, which must be enforced to guarantee people dignity in all parts of the world.

Nevertheless, housing issues are often treated by the public and private agents only as access to a roof and set of walls, in other words, shelter. However, housing is an important element that guarantees dignity and citizenship for people, and the deficit of access to housing leads individuals to seek public shelters (Culhane, Lee, \& Wachter, 1996), among other options that are available in various locations such as homeless camps or landless. In this context, Gronowski (2019) points out that 100 million people around the world are feeling to be homeless, moreover based on data collected in 2014, by the methodology of the João Pinheiro Foundation, the Brazilian housing deficit reaches 6,198 million families (FIESP, 2016).

As stated by Oliveira and Maciel (2016), it is important to stress the importance of the housing right because without a suitable place to protect oneself and their family, without a place for the individual to enjoy their privacy, certainly there will be no way to proclaim the essence of the principle of the human person dignity (article 1으. III, Federal Constitution), since it demands the satisfaction of basic needs for a dignified life.

The Federal Homelessness Partnering Strategy (HPS) defines the "homeless" as individuals who live on the streets, spend their nights in public shelters, and stay overnight in unhealthy places. In addition, these individuals continually alternate in strangers houses, friends, and relatives (Hamilton, 2014). According to UNHABITAT (2003), housing is also advocated by international organizations and agreements such as The International Convention on the Elimination of All Forms of Racial Discrimination (1965); The Convention on the Elimination of All Forms of Discrimination 
Against Women (1979); The Convention on the Rights of the Child (1989); the Convention Relating to the Status of Refugees (1959); The International Convention on the Protection of the Rights of All Migrant Workers and Members of Their Families (1990).

Another aspect that should be highlighted is access to decent housing. A study by the United Nations Human Settlements Program (UNHABITAT, 2014) has used the generic term "favela" to represent a wide range of low-income human settlements with precarious living conditions. This type of housing space characterizes one of several manifestations of poverty. Thus, it can be said that housing can materialize and externalize the condition of precariousness and sub-citizenship of an individual, especially when the condition of housing is precarious in order to compromise the integrity and well-being of people (Malone, 2018).

Therefore, the question of housing is directly related to the condition of the life of the individuals (Alves, 2010; UNHABITAT, 2014; ONU, 2014), so some general characteristics that are attributed to favelas housing are: lack of access to basic public services such as potable water, sanitation, electricity, asphalting, etc., precarious or illegal housing, and inadequate structures.

Curtis and Cosgrove (2018) explain that in the environment that lacks dignity housing there is garbage everywhere, this situation makes children's playgrounds on top of a giant mound of trash. As can be seen in the description of the conditions of this type of housing, it removes from the individual his capacity to exercise full citizenship in the manner described by Rawls (2005), besides putting their family's life at risk, which characterizes only one space that can be considered as a shelter. Therefore, it can be verified that access to housing in its proper form can guarantee access also to goods and services that promote full citizenship. Therefore, adequate housing should include: security of tenure for people with the right to live without fear of being removed, as well as excessive or unexpected threats. Other rights related to housing are the availability of services, access to infrastructure and public and/or private facilities such as potable water, basic sanitation, gas and electricity, etc. (ONU, 2014; ORIBER, 2016).

In addition, we advocate that housing must have a cost for the acquisition or affordable rent to don't compromise the family budget for spending on food, culture, leisure, etc., and the housing could provide good protection against cold, heat, rain, wind, humidity, and also against threats of fire, landslides, floods and any other factors that endanger the health and life of people. It is also necessary to consider the shelter size and the number of rooms that must be consistent with the number of residents. These aspects seem to be the basic conditions arising from housing, but it is not what matches the reality of many people around the world as point out Curtis and Cosgrove (2018), Gronowski (2019), and Malone (2018).

Another aspect related to housing that should be discussed is that no discrimination vulnerable groups. The state has to build, based on its social function, it adequate housing policies to promote accessibility to vulnerable groups in society. Vulnerable groups could be understood as elderly, women, children, people with disabilities, people with human immunodeficiency virus (HIV), victims of natural disasters, etc. They should also be in localities that can offer opportunities for economic development (employment and income), cultural (leisure), and social (spaces of public living as parks), among other aspects related to hygiene and sanitary conditions of the housing. Nevertheless, housing must have materials used in construction that express both, the identity and the cultural diversity of their residents. 
We can say that these issues really bring a high degree of complexity to promote public policies related to housing. However, these issues promote insertion of individuals from society towards full citizenship, hence based on these characteristics; we can affirm that adequate housing provides access to a decent life and a means to obtain full citizenship (ONU, 2014; ORIBER, 2016; UNHABITAT, 2003; UNHABITAT, 2015). In addition, dignified housing must provide individuals with a fixed address that gives them recognition as an economic-social being, that they can also petition the state for improvements in their locality, as well as exercise labor, social and financial activities for their well-being.

Another aspect that should be highlighted here is that in addition to social and economic issues, environmental issues must also be taken into account when dealing with housing problems. There is no common point in building, or even permitting, regions that compromise natural resources such as vegetation and water (Curtis \& Cosgrove, 2018; Spaans \& Waterhout, 2017). These points are not only a citizenship question, as Spaans and Waterhout (2017) stress, these issues stay linked with city resilience to inspire cities to reflect upon the extent to which private and public services are capable of adapting to new situations of crises or population growth. Therefore, it is possible to say that the management of housing areas impacts directly the way of cities are constructed and how the infrastructure to guarantee a fair society.

Next, there will be a discussion on how the organization of cities should be done.

\subsection{The segregated way of organizing cities}

In the early twentieth century, the social analysis of urban space was developed by the Chicago School, based mainly on the research of Ernest Burgess and Robert Park. Caldeira (2000) explains that these researches worked on the assumptions of social ecology to explain the distribution of the population by cities. The key idea was that there were natural areas where homogeneous communities would emerge with their own value systems represented by multiple symbols (Bell \& Jayne, 2017). These natural areas were found in all North American, Canadian and English cities of that time, and this model of city representation was organized in concentric circles occupied by administrative, commercial, industrial and residential activities (Caldeira, 2000).

In addition, the existence of an urban way of life was the result of this spatial composition that allowed the identification of communities that came to inhabit the city, becoming neighborhood units of mutual aid and networks of social relations based on reciprocity and exchange (Arantes Neto, 2000). We can say that this relationship of social symbiosis is not new, as Tocqueville (1998) explained, it arose from the interaction between people who defended their common areas as square and streets. With regard to the theoretical paradigm, the idea of concentration in urban areas leads to Durkheim's (2013) concepts of community and society, their forms of sociability, and the social division of labor that he conceived. Consequently, we infer that based on such concepts, segregation is could be understood as the specific social or geographic position that put particular social group away in relation to others.

Therefore, the spatial distance in relation to the concept of segregation is considered as an expression of social distance, that is, something imposed top-down, and that now from the point of view of self-segregation would come from each one, from each social actor and not only from 
socioeconomically oligarchic. We can say what segregation seems to be something less natural and more deterministic than self-segregation, but the first one is more practiced and felt as in the case of closed condominiums (Sassen, 1994; Costa \& Tavares, 2009). Therefore, individuals are led in one way or another to act in accordance with racial, ethnic, social position, economic power, and so on. The segregation action adopted by individuals functions as a defense mechanism, a way of protecting oneself from the effects of the fragmentation of individuality provoked by living in cities.

Souza (2006) and Negri (2010) shown that It is believed that spatial segregation is the product of logics that are essentially individual, which are collectively perceived by the affinity of various signs that promote self-segregation: to raise several fences, walls, and distances, with individual and multiple sociological consequences. According to Richardson Jr. (1977), agreeing with the idea of self-segregation, neoclassical thinking considers individual abilities and choices as determining factors for the occupation of certain places within cities. In the same way, we can stress that, for example, when people take account of their socioeconomic or religious condition different from the others, they would take advantage of the feasible opportunities to withdraw (or protect themselves) by voluntarily and consciously isolating themselves.

Lojkine (1979) argues that the state would eventually lead to these ideological imperatives, something to compose, again, a certain sociological-Marxist relationship in which the State, and the capital, would end up taking control of things (Caldeira, 2000). Follow on this line of thought, we can explain that the state would play a key role in the social context of the division of space in cities. It would happen from public politics, where the state sometimes is identified as only a representative of the ruling classes. As Caldeira (2000) and Negri (2010) have pointed out, the State is always mediating everything.

We evidence after shown here the lack of housing rights and a socio-spatial fragmented society that socio-spatial self-segregation results from dialectical forces, often opposed, mainly seen as assuming the characteristics of capitalist societies. Moreover, this situation can be perceived as also resulting from certain social struggles marked by the unequal appropriation of the territory, consumer goods, and weakness of housing categories as previously indicated (Souza, 2006). In this sense, Sassen (1994) mentioned the impact of globalization on cities and the increase of sociospatial self-segregation mainly in urban spaces, as in the case of closed condominiums surrounded by high walls as shown in Figure 1.

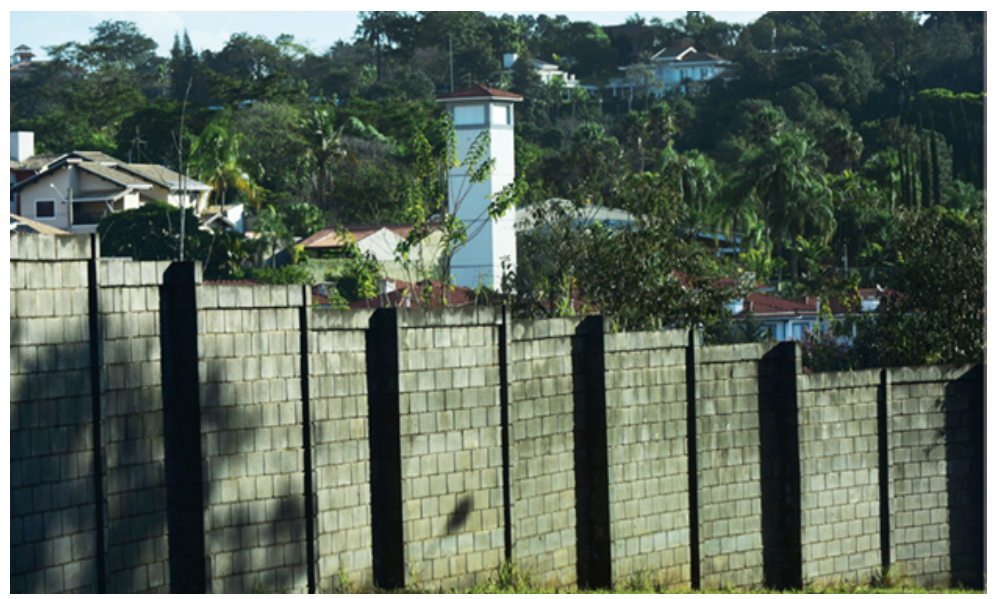

Figure 1: Allusion to closed condominiums 
Source: Souza (2006, p. 23).

For Sassen (1994) three mechanisms are often considered as being the central causes of socio-spatial self-segregation, are them:

a) The diffusion of liberal ideas throughout the planet that is motivated by globalization that eventually end up demanding for changes in the regulatory model of urban policy, which has contributed to real estate market inflation;

b) The final prices of real estate for purchase or rental that have become one of the most important mechanisms of distribution and occupation of urban spaces, which determines the places of residence in each territory for each one, it forcing and reinforcing the importance of income inequality in respect to the appropriation of urban space;

c) Privatization of certain urban services that increase social inequality, such as education, leisure, etc.

It can be said that these are constituent factors for socio-spatial segregation which is a direct effect of the productive restructuring and the transformations caused in the urban space, mainly of big cities like the metropolitan region of São Paulo. In addition, studies such as Hughes (2004) and Campos and Almeida (2016) have described a situation of socio-spatial segregation and inequality that takes into account the fact that the transformation of space in large cities has different origins. Nevertheless, it can be said that this situation can still vary according to the historical and social matrix of each country, in relation to historical dependence what constitutes a situation of belonging in each locality (Spaans \& Waterhout, 2017; Culhane, Lee, \& Wachter, 1996; Gronowski, 2019).

Although we have dealt here with factors that lead to socio-spatial segregation, the people chosen for the isolation or segmentation of society is recognized as self-segregation. According to Pozzo (2011), residential segregation consists of a spatial relationship, territorial separation or proximity between people and families belonging to the same social group. This socio-spatial selfsegregation occurs in any social class, although it is most strongly practiced by isolated elites in their homes, buildings, and condos surrounded by high walls as shown in Figure 1 (Sassen, 1994).

Méndez and Otero (2018) explain that the existence of neighborhood conflicts is related to several aspects of socio-spatial inequality. We stress that the most evident socio-spatial selfsegregation is related to income and to social differences, given that increasing inequalities do not allow contact between different social groups. This situation invariably leads individuals to overcome socio-economic obstacles to seek goods and services that are markedly separated by so many walls, clearly existing or painted by physical barriers or not. This discussion will be deepened in the next section. 


\subsection{Visible and invisible walls and access to citizens 'rights}

Stories about the Middle Ages tell of walls that protect castles, principalities, and villages from attacks that came from enemies with different purposes. The search for power, the conquest of territories by the greed and riches existing in a certain place, or by the strategic location of resources that are attractive (Silva, 2011). We can affirm that often the visible walls separate ethnicities, races, political systems, tourist spots, neighborhoods, business organizations, social groups, etc. Nowadays people erect walls around their houses to delimit their property and to protect them from thieves and other intrusions that somehow attack property law and their right to privacy. The housing complexes, as they do with the closed condominiums, build walls around them away from everything. Companies build walls with the same purpose, more strongly thinking about the protection of their assets since they store properties, values, and information vital to their business (Arantes Neto, 2000).

In the same way, individuals or groups of individuals decide to build walls to promote selfsegregation, especially those starting people who feel unprotected or threatened in their individuality (Maricato, 2001; Méndez \& Otero, 2018). We can infer that the same behavior is incorporated by those who feel excluded from the physical and also psychosocial territories of which they belong (Souza, 2006; Negri, 2010; UNHABITAT, 2014).

Although the built of walls has an excuse for protection, they tend to represent other motives to ward off what people find strange. Individuals tend to externalize the desire to distance themselves, for example, from the poorer classes of the population, to distance themselves from urban environments with diverse architecture, to delimit what is beautiful from what is ugly. This situation leads the lines erected on bricks to represent a pseudo-reality in which on one side are the chosen ones, and on the other side, those that are strangers to them. This argument is often used to say who can have access to a certain standard of living, and who can not access it (Fleury; Subirats \& Blanco, 2008; Sen, 2010). After an analysis in previous studies such as Malone (2018) about how children live in cities, Grownowski (2019) about the right to a nationality and the right to adequate housing, and Mendonça, Andrade and Diniz (2019) hypersegregation of the Brazilian metropolitan elites, we can points to an almost infinite relation of factors to promote such surroundings of exclusion. Figure 2 shows an emblematic photo of the city of São Paulo that well exemplifies what is described until here. 


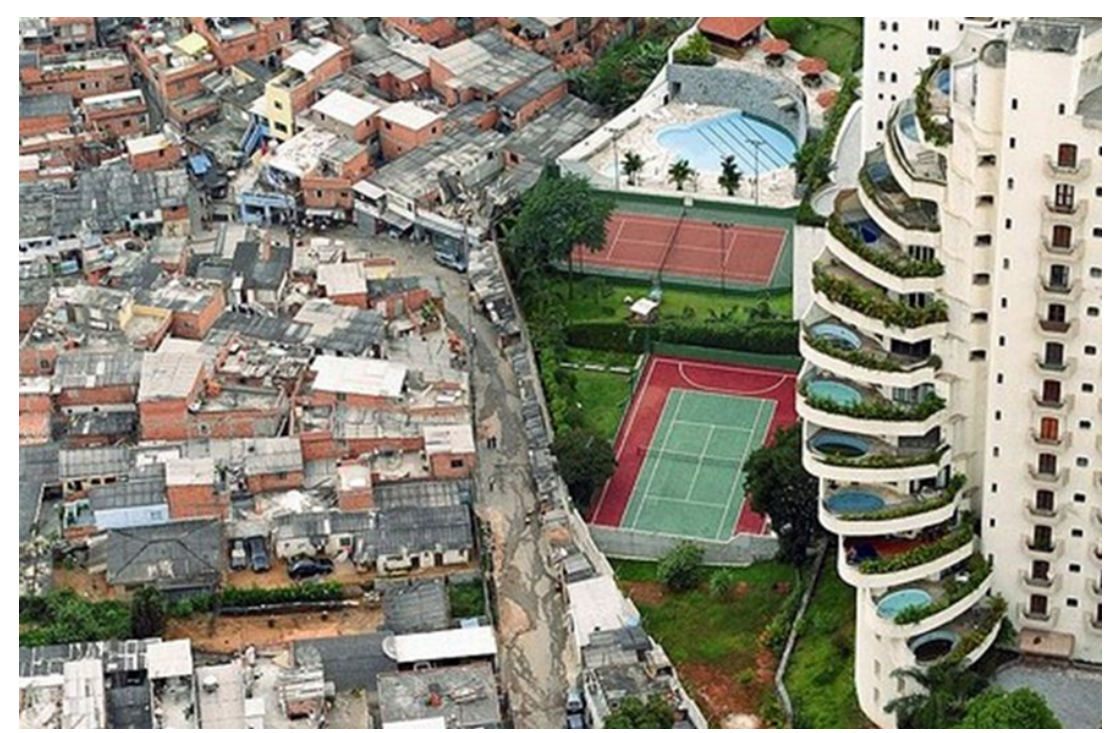

Figure 2: Self-segregation favela-condominium in the neighborhood of Morumbi in São Paulo Source: Gohn (2010).

Souza (2006) pointed out that people choose their shelters based on certain identification with a behavioral pattern, this means that people adopt a lifestyle that is delimited and shaped by their dwelling. This situation indicates how some people don't want to have as individual's neighbors of low socioeconomic status, or who somehow approach and endanger a conquered standard of living as can be seen in Figure 2.

Therefore, mainly in Brazil walls really separate patrimonies and pretended feelings of wellbeing, it fragmenting strata of society as if we were living an explicit caste system. Thus, an upper class builds walls to separate itself from the lower classes. This is a situation in which spaces are destined to a certain type of individuals and behaviors, is that these spaces can have physical walls or not (Fleury, Subirats \& Blanco, 2008). In fact, whether socio-spatial self-segregation carried out spontaneously by each family or institution, or it is induced by large real estate corporations, one wants to impose classifications and make differences.

One point that draws attention in this discussion of spatial self-segregation, sometimes in an implicit way, is that even people who struggle against discrimination, they do not want to open the windows of their homes built under luxurious construction standards and come across the vision of favelas, street dwellers, people of different socioeconomic conditions. In line with this, physical evidence of a public policy to lack of housing can be perceived in public roads, alleys, and state apparatuses for the provision of services such as bus terminals, schools and health posts (Silva, 2011). In this way, some people manifest desire to self-immunize from different living standards of their own, which in fact have very significant urbanistic but also psycho-sociocultural implications. 


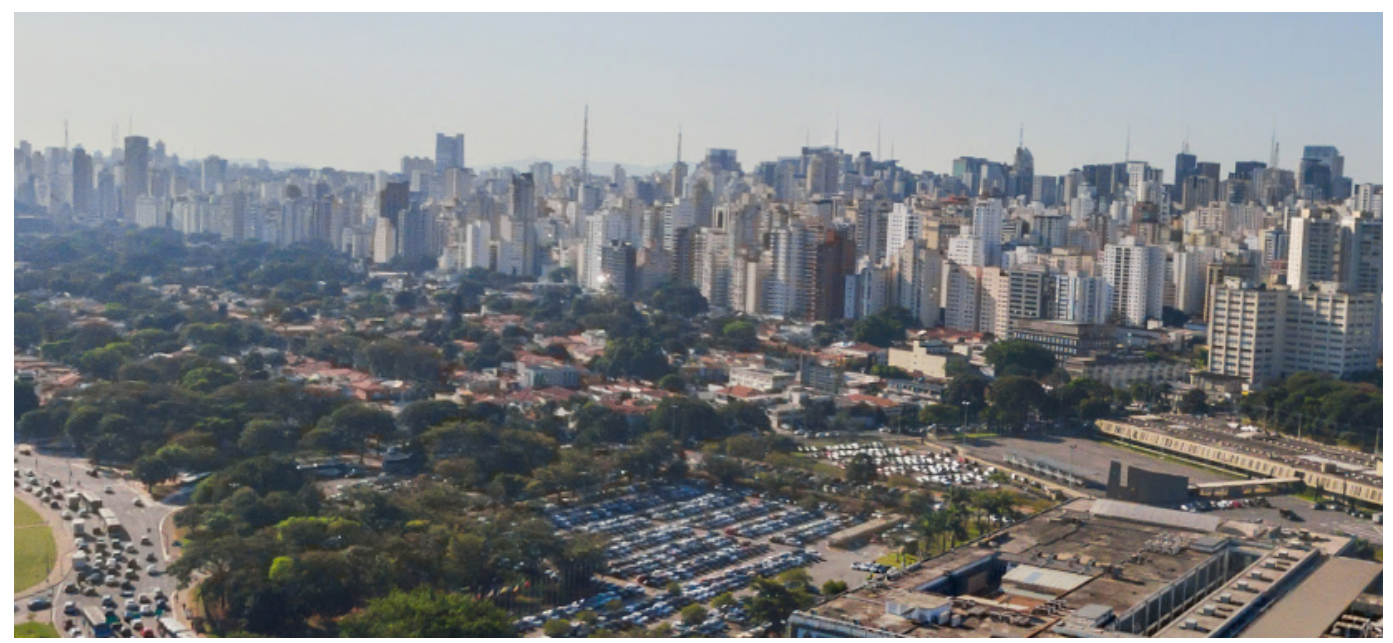

Figure 3: Ibirapuera Park Region - São Paulo.

Source: Google Earth (https://goo.gl/oyFH37)

We can give the example of socio-spatial self-segregation the comparison between the New Jersey and New York suburbs, populated by high-standard homes without any kind of wall, and the closed condominiums of the great metropolis of São Paulo and Rio de Janeiro. In São Paulo, an example would be the streets near the famous Ibirapuera Park, where there are condominiums surrounded by high walls, cameras, and local security personnel as can be seen in Figure 3 .

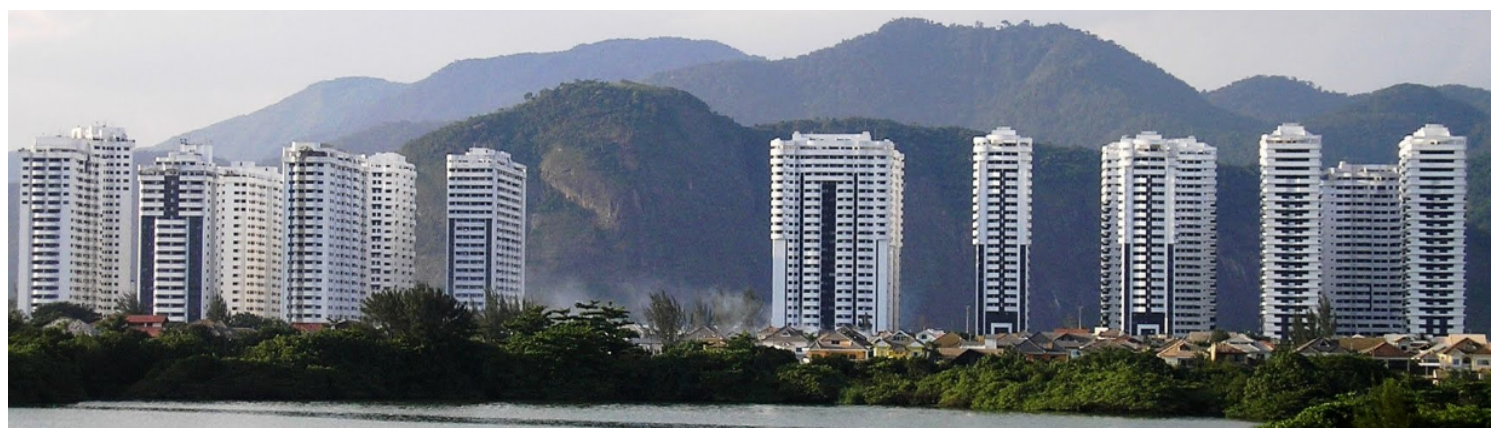

Figure 4: Condos of Barra da Tijuca - Rio de Janeiro.

Source: Google Earth (https://goo.gl/ZCFWRT)

In Rio de Janeiro, the buildings of Barra da Tijuca have physical barriers that serve to separate the condominiums of luxurious buildings from the neighborhoods and nearby streets (as seen in Figure 4). Thus, this difference of socio-economic pattern, which is said to be high, determines that a group survives within walls, sharing their lives with each other, and another group that lives apparently unfortunate, disputing goods, public and private services, as can be seen in Figure 5 (Frey \& Duarte, 2006). 


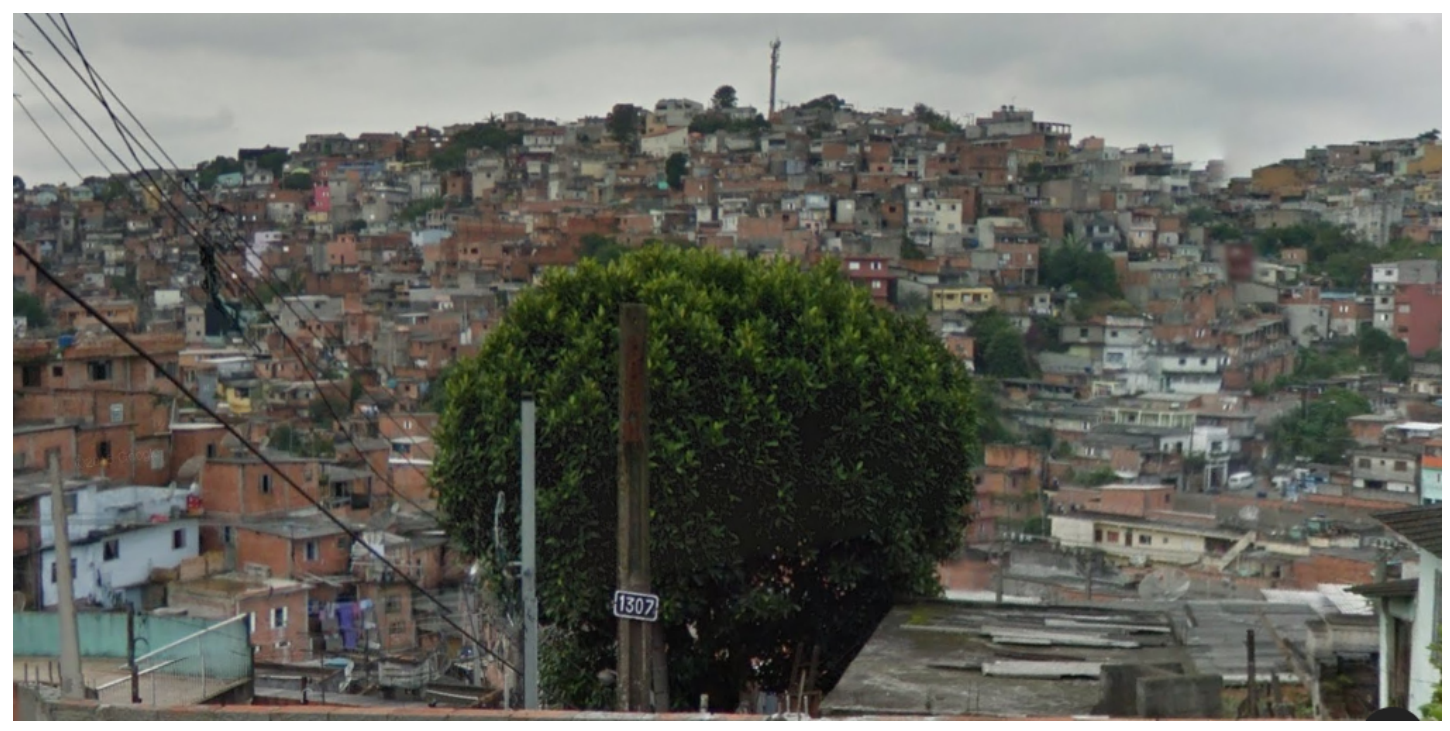

Figure 5: São Paulo's city outskirts

Source: Google Earth (https://goo.gl/9jgEfK)

Another example that denotes the socio-spatial self-segregation between the individuals of a society is those long concrete walls housing hundreds of shops, i.e., the well-known shopping malls. Aside from the great hermetic constructions to protect and separate consumers that are actually able to buy from those who do not have such apparent power. In this way, the surroundings of the shopping centers are surrounded, usually by grids and cameras. However, the separation of these individuals is not only physical but psychosocial because it directly interferes with self-esteem and codes of behavior such as social attire and rituals.

It should be noted here that walls and grids also change the urban landscape of other organizations, which characterizes architectural modifications of the cities linked to such divisions. This is the case of schools and universities that are blocked by grids and walls, which prevents contact from the external environment and vice versa, for those who have not been selected to belong to such groups stay away to this select space. Even worse than it may seem to be the example of basic and secondary schools in Brazil, as often compared, as Arantes Neto (2000) assumed, to a center of containment of people, walled up that prevent students from leaving, in great reference to prisons and detention centers.

However, as the focus of this discussion is on socio-spatial self-segregation in housing, it is worth noting that authors such as Fleury, Subirats, and Blanco (2008) presented a very important aspect that is related to the formation of spaces with a high degree of social homogeneity, areas to denote luxury in large cities, as in areas of high concentration of poor people. We can stress that the evidence of areas such as shopping malls and closed condominiums, could be seen as a barrier of social-spatial convivence, it favors the emergence of subjective perceptions about highly segregated residential locations. The perceptions of such areas can be positive in terms of the prestige that exclusive spaces lend to their inhabitants or to their habitual visitors.

However, one part of the population can have a negative perception, as in the case of degraded urban areas such as hillsides and areas of springs, and these areas are marked by a certain perversity that stigmatizes its inhabitants (Frey \& Duarte, 2006). Penna and Ferreira (2014, p. 25) 
said that these degraded environments expose the vulnerability that "is defined as a social risk characterized by the concentration of the precariousness of collective services and of public investments in infrastructure in the territory, thereby causing social deprotection of the neediest communities".

The characteristics of such poorer neighborhoods and housing nuclei resemble ghettos marked by invisible walls separating them from the rest of the city. Bell and Jayne (2017) point out that ghettos, red-light zones, neighborhoods, and areas where there are concentrations of marginalized groups and activities, often could be divided along the lines of class and ethnicity. Additionally, the authors said that these kinds of places are bound up in the political, economic, social, spatial and cultural forces which have led to the proliferation. This situation corroborates with what are researched by Culhane, Lee, \& Wachter (1996), Méndez \& Otero (2018), and Gronowski (2019). These authors evidenced that people self-segregate because they feel themself the prejudice that instigates them to such exclusion. This situation constitutes large housing nuclei or even entire neighborhoods that, although accessible to everyone, are occasionally delimited by the architecture to involve them. Figures 2 and 5 show examples of socio-spatial self-segregation.

According to Frey and Duarte (2006), when self-segregation in closed condominiums is no longer just an upper-class option, it becomes a middle-class posture, this situation becomes a process of denial of the city in one of its essential characteristics. These harmed characteristics are related to the multiplicity and diversity of social strata, which the social-space should help to form a fairest urban life.

For Pozzo (2011), social-spatial self-segregation in poorer places arises from invisible walls that are built, and these walls are built by residents in the common identification of some social processes. We can point out that this situation is a result of no access to public facilities, and private services which could contribute to the culture, education, among others. It is the case also of low income, unemployment or illiteracy to characterize such individuals who exclude themselves from other groups in the same locality. This type of self-segregation creates separations not visible to all, but which are outlined by subtle contours almost embodied in the surrounding environment. It can be said that lack of state, in providing services that guarantee full citizenship, allows other social forces to take their place (Curtis \& Cosgrove, 2018;).

Other points that lead to socio-spatial self-segregation can be perceived in Brazilian cities such as Belo Horizonte metropolitan region shown by Mendonça, Andrade, \& Diniz, (2019), and the Paranaences urban centers by Schmidt, Mendes, \& Töws (2013). They are evidenced by behaviors and beliefs that categorize places by drug use, family disintegration, and crime. This type of social reproduction stimulates still more the issues related to a position of self-isolation of the individuals (Torres et al., 2003; Negri, 2010; Malone, 2018). In addition, we stress that factors related to class conditions actually end up affecting such a segregating condition. Therefore, in several Brazilian metropolises, and especially for these researches in the Metropolitan Region of São Paulo, the inner urban areas and peripheral zones are strongly marked by the features of exclusion, with needs that overlap with the problem itself. This situation causes only low-income families to remain in degraded areas within the city, in a process of socio-spatial self-segregation basically centered on poverty (Souza, 2006). 
Fleury, Subirats, and Blanco (2008) defended the idea that socio-spatial self-segregation takes the form of spatial and social isolation due to the distance from territories that are well equipped in terms of urban and cultural services. The authors also reported that even in Europe, family disintegration and social disqualification eventually led to harmful consequences for some populations. Unfortunately, this situation reflects years of segregation from society, which can be difficult to face. Otherwise, public managers must deepen discussions to promote actions that go beyond physical issues such as public facilities.

In a very aggravating way, there would also be an operational concept in this territorial apartheid, again referring to certain social immobility promoted this time by opportunistic governments and individuals, on one side, and on the other composed by the wealthiest individuals. Thus, we recommend promoting a more open discussion about rights and housing would take into account a relationship between access to society goods and services and socio-spatial selfsegregation, which would facilitate urban logistics. This would also mitigate the need to build more walls, on the contrary, it would stimulate public policies to bring public services and facilities to certain localities (Souza, 2006; Fleury, Subirats \& Blanco, 2008; UNHABITAT, 2015). In addition, this type of promotion would create more opportunities and benefits in different areas of the cities, which would also reduce vulnerability and social exclusion in less favored areas (Arantes Neto, 2000; Spörl \& Seabra, 2011).

Additionally, we can say that social reproduction evidenced is based on a contemporary subject that follows an anthropologically constructed order of models repetition, stigmas, traditions, and diverse cultural traits. This historical repetition of behaviors comes from families composed of several generations living in the same building or in the same region. This situation generates certain passiveness, and this self-reproduction of socio-spatial self-segregation behavior aimed at inhabiting a certain region is also reproduced in the recreational activities shared by an expressive number of people of the same community. An example of this social reproduction can be evidenced at a time when the square was one of the most attractive points of cities (Souza, 2006; Ganea, 2007; Arantes Neto, 2000).

Although there is an effort to deal with socio-spatial self-segregation around the world, the task of removing people from a comfort zone by physical and social isolation requires emergency actions by various social actors. Therefore, from public managers, it is a necessary action to change this dramatic situation and to apply the various management instruments in our political-legal order. We enforce that the purpose of this kind of action should be to assert the fundamental right to goods and services, public or private, for all citizens in their localities. In resume, we defend here the idea of housing can not be associated only with the understanding of a mere shelter, but with a set of elements related to fundamental rights that can guarantee subsistence and human dignity (ONU, 2014; Maciel, 2016). Thus, the rights to mobility, education, health, leisure, among others, must be present when planning or discusses urban space. 


\section{FINAL CONSIDERATIONS}

In this study was verified that the discussions on housing are issues that deal with access to a full citizenship condition which includes freedom and access to public health, sanitation, and education services. Furthermore, the issues treat here explicit the access to the situation of the individual economically active who can use your address to access accounts at banks, purchases of products, among others.

It is worth noting that even when studies on socio-spatial self-segregation are based on different theoretical frameworks, several observations on the realities of urban spatial division invariably point to the negative consequences that voluntary or involuntary isolation of social groups may cause. We can affirm that the physical and social isolation of groups weakened by social and economic issues can be considered a short-term solution, a form of protection against discrimination, or just a way of guaranteeing subsistence. On the other hand, the case of voluntary isolation of high-income groups in residential buildings and closed condominiums could cause the disadvantages related to the restrictions imposed on forms of sociability, which are often restricted to intramural areas. This last group stays prisoners of their condition without access to public areas. We can say that nobody wins in a society that wants to be just with socio-spatial self-segregation.

The self-segregation comes from economic and social issues that end up causing an enormous potential to lose relevant chances of social interaction. Moreover, we stress that this situation also creates conflicts in the intersections of realities between social strata. The constructed walls, whether physical or not, expose a fragility in the urban issues, and the difficulty for interaction between individuals considered different in the urban space. Thus, labels and stigmas are assigned according to the place where a person resides. It is not difficult to notice people embarrassed to tell the neighborhood or locality that they reside in. It can be said that this situation also removes the subjectivity of this individual because it causes its individuality to be surpassed by the place where he lives.

Particularly, when one considers that the real estate developers have launched your business impetuously in the purchase of land in different regions of Brazil, it's caused by the policy of speculative expansion with a strong increase of prices that reinforce a high social and environmental cost of Brazilian urbanization.

Therefore, at the end of this article, we concluded that the discussion about housing should not be based only on the division of geographical spaces. Other issues related to beliefs and attitudes must be raised, as the simple insertion of individuals into certain spaces, can cause problems through psycho-social segregation. Thus, housing areas should not be thought only as shelter or protection. A house can be called this way when it provides individuals with a life full of dignity and rights and freedom in a fair and organized society.

Based on the researched studies, it is possible to say that more studies are necessary to address not only physical issues related to housing but also cultural, social and emotional ones. Housing issues cannot be related only to protection or livelihood. We can say that socio-spatial selfsegregation leaves a deep guidemark on individuals, who correspond to their identity and attitude towards the rest of society that is not part of this circumscribed space. 


\section{REFERÊNCIAS}

Alves, C.C.N. (2016). Direito à moradia. Dissertação Mestrado. UFPR, 2010. Retrieved from: http://acervodigital.ufpr.br/bitstream/handle/1884/24334/Carolina\%20Caraiba1.pdf?sequen $\underline{\mathrm{ce}=1}$

Arantes Neto, A. A. (2000). Desigualdade e Diferença: cultura e cidadania em tempos de globalização. São Paulo: UNICAMP.

Barbosa, A.G. \& Costa, A.A. (2011). Implicações socioespaciais, econômicas e jurídicas em condomínios fechados horizontais. Mercator - Revista de Geografia da UFC, 10(21), 49-61.

Bell, D., \& Jayne, M. (2017). City of quarters: urban villages in the contemporary city. Routledge.

Caldeira, T.P.R. (2000). Cidade de Muros: crime, segregação e cidadania em São Paulo. São Paulo: Editora 34/Edusp.

Campos, R.B.A. \& Almeida, E.S. (2016). Decomposição Espacial dos Preços de Imóveis Residenciais no Município de São Paulo. Anais... In: XLIII Encontro Nacional de Economia [Proceedings of the 43rd Brazilian Economics Meeting]. ANPEC-Associação Nacional dos Centros de Pós-graduação em Economia [Brazilian Association of Graduate Programs in Economics].

Costa, A.A.D. \& Tavares, M.A.A. (2009). Condomínios horizontais fechados e transformações socioespaciais na cidade de Natal/RN. Mercator - Revista de Geografia da UFC, 8(16), 61-75.

Culhane, D. P., Lee, C. M., \& Wachter, S. M. (1996). Where the homeless come from: a study of the prior address distribution of families admitted to public shelters in New York City and Philadelphia. Housing Policy Debate, 7(2), 327-365.

Curtis, B., \& Cosgrove, S. (2018). Building a framework for understanding poverty. In Understanding global poverty (Vol. 1, No. 24, pp. 1-24). ROUTLEDGE in association with GSE Research.

Durkheim, E. (2013). De la division du travail social. Paris: Presses Électroniques de France.

Ferreira, R.F.C.F. \& Biasotto, R.C. (2012). Caderno didático: políticas públicas e direito à cidade: política habitacional e o direito à moradia digna: programa interdisciplinar de formação de agentes sociais e conselheiros municipais. Rio de Janeiro: Letra Capital.

FIESP. (2016). Levantamento inédito mostra déficit de 6,2 milhões de moradias no Brasil. Retrieved 05.03.2017. From: http://www.fiesp.com.br/noticias/levantamento-inedito-mostra-deficit-de62-milhoes-de-moradias-no-brasil/

Fleury, S., Subirats, J. \& Blanco, I. (2008). Respostas Locais para Inseguranças Globais: Inovação e Mudança no Brasil e na Espanha. Barcelona: Fundação CIDOB.

Frey, K. \& Duarte, F. (2006). Auto-segregação e a Gestão das Cidades. Revista Ciências Sociais em Perspectiva, 5(9). 
Gadea, C.A. (2007). A crítica pós-moderna: analítica da interação e da sociabilidade. Ciências Sociais Unisinos, 43(1), 68-78.

Gohn, M.G. (2010). Morumbi: the contradictory region-neighborhood of São Paulo. Caderno CRH, 23(59), 267-281.

Gronowski, B. (2019). The Right to a Nationality and the Right to Adequate Housing. The Statelessness and Citizenship Review, 1(2), 239-262.

Hamilton. (2014). City of the understanding the homeless. Retrieved 26.11.2016. From: http://www.sprc.hamilton.on.ca/wp-content/uploads/2010/05/COLLAB-On-Any-Given-NightHomelessness-Indicators-Report-May-2010.pdf

HPS. (2015). Homelessness Partnering Strategy Directives 2014-2019. Retrieved 26.11.2016. From: http://www.esdc.gc.ca/eng/communities/homelessness//index.shtml

Hughes, P.J.A. (2004). Segregação socioespacial e violência na cidade de São Paulo: referências para a formulação de políticas públicas. São Paulo em Perspectiva, 18(4), 93-102.

Lojkine, J. (1979) Existe um renda fundiária urbana? Marxismo e Urbanismo Capitalista: textos críticos. São Paulo: Editora Ciências Humanas.

Malone, K. (2018). Cities of Children. In Children in the Anthropocene (pp. 57-80). Palgrave Macmillan, London.

Maricato, E. (2001). Brasil, cidades: alternativas para a crise urbana. Petrópolis: Vozes.

Méndez, M. L., \& Otero, G. (2018). Neighbourhood conflicts, socio-spatial inequalities, and residential stigmatisation in Santiago, Chile. Cities, 74, 75-82.

Mendonça, J. G. D., Andrade, L. T. D., \& Diniz, A. M. A. (2019). Hypersegregation of the Brazilian metropolitan elites in the 2000s: interpretations based on the Belo Horizonte Metropolitan Region. Cadernos Metrópole, 21(44), 29-53.

Negri, S.M. (2010). Segregação sócio-espacial: alguns conceitos e análises. Coletâneas do Nosso Tempo, 8(08).

Oliveira, J.M. \& Maciel, J.J.P. (2016). O acesso à moradia como direito fundamental do cidadão. Synthesis Revista Digita FAPAM, 5(5), 205-225.

ONU. (2014). Relatoria Especial para o Direito à Moradia. Retrieved 03.02.2020. From: http://direitoamoradia.org/?page id=46\&lang=pt

ORIBER. (2016). GPS - Guia de Gestão para a Sustentabilidade. Retrieved 03.02.2020. From: https://ecossociodesenvolvimento.org/riber-rede-iberoamericana-do-projeto-milenio/

Penna, N.A. \& Ferreira, I.B. (2014). Desigualdades socioespaciais e áreas de vulnerabilidades nas cidades. Mercator - Revista de Geografia da UFC, 13(3), 25-36. 
Pozzo, C.F.D. (2011). Territórios de Autossegregação e de Segregação Imposta: Fragmentação Socioespacial em Marília e São Carlos. Prudente: Universidade Estadual Paulista.

Rawls, J. (2005). Political liberalism. Columbia University Press.

Reani, R.T. \& Segalla, R. (2006). A situação do esgotamento sanitário na ocupação periférica de baixa renda em áreas de mananciais: consequências ambientais no meio urbano. Encontro da Anppas, 3.

Richardson Jr., L. (1977). Propertius. Elegies I-IV. Norman, Oklahoma: University of Oklahoma Press.

Sanfelici, D. (2016). Centralização do capital no setor imobiliário e reconfiguração das metrópoles. Mercator - Revista de Geografia da UFC, 15(2), 7-21.

Sassen, S. (1994). Cities in a world economy. Thousand Oaks: Pine Forges.

Schmidt, L.P., Mendes, C.M. \& Töws, R.L. (2013). Urbanização e dinâmica socioespacial em centros urbanos paranaenses. Mercator - Revista de Geografia da UFC, 12(28), 55-66.

Sen, A.K. (2000). Desenvolvimento como liberdade. São Paulo: Companhia das Letras.

Silva, S.R.M. (2011). Transformação das abordagens urbanísticas e ambientais na política territorial brasileira: confluências e divergências no direito de propriedade, nos instrumentos de gestão e no desenho institucional. Tese de Doutorado. São Carlos: UFSCar.

Souza, M.L. (2006). A prisão e a Ágora: reflexões em torno da democracia do planejamento e da gestão das cidades. Rio de Janeiro: Bertrand Brasil.

Spaans, M., \& Waterhout, B. (2017). Building up resilience in cities worldwide-Rotterdam as participant in the 100 Resilient Cities Programme. Cities, 61, 109-116.

Spörl, A. \& Seabra, O.C.L. (2011). A lei de proteção aos mananciais versus a prática social de ocupação na Bacia do Guarapiranga. Revista do Departamento de Geografia, 11, 113-129.

Tocqueville, A. (1998). A democracia na América: leis e costumes: de certas leis e certos costumes políticos que foram naturalmente sugeridos aos americanos por seu estado social democrático. São Paulo: Martins Fontes.

Torres, H.D.G., Marques, E., Ferreira, M.P. \& Bitar, S. (2003). Pobreza e espaço: padrões de segregação em São Paulo. Estudos Avançados, 17(47), 97-128.

UNHABITAT. (2003). Monitoring housing rights Developing a set of indicators to monitor the full and progressive realization of the human right to adequate housing, United Nations Human Settlements Programme. Retrieved 03.02.2020. From: https://www.un.org/ruleoflaw/files/3674 40241 UNHRP-WP-01.pdf

UNHABITAT. (2014). Global Urban Lectures - all packages. Retrieved 03.02.2020. From: $<$ http://unhabitat.org/wp-content/uploads/2014/03/Urban-Lecture-Series-2014-03-27-lowres1.pdf 
UNHABITAT. (2015). HABITAT III ISSUE PAPERS2O - HOUSING, United Nations Task Team on Habitat III. Retrieved 03.02.2020. From: http://habitat3.org/wp-content/uploads/Habitat-IIIIssue-Paper-20 Housing-2.0.pdf

Vianna, L.F.H. (2016). O direito à moradia como um direito humano: mecanismos de efetivação da função social da propriedade no município de Palmas-Tocantins. 117f. 2016. Dissertação (Mestrado Profissional Interdisciplinar em Prestação Jurisdicional e Direitos Humanos). Universidade Federal do Tocantins. 